\title{
Books and Resources for Review
}

Anthropology in Action is always happy to hear from potential reviewers at all stages in their academic careers, for books, films or other media.

We currently have a number of books and video resources awaiting review. If you are interested in reviewing anything on the list below, please contact the reviews editor David Orr (d.orr@sussex.ac.uk). We welcome reviews of around 800 words for a single book, but we are also keen to include review articles comparing two or more works, for which the word length is negotiable. Please also be aware that we can request recent publications (within the last year) from publishers, so do feel free to let us know of any books that you would like to review within the field of applied anthropology, and we will do our best to get them for you. Also note that many publishers routinely send pdf or e-copies of publications rather than hard copies.

Beyond books, we are particularly keen to broaden reviews to other topical content with relevance to applied anthropology including exhibitions, films, websites, blogs, and events. Furthermore, in addition to regular reviews, we feature occasional reviews under the title 'To see ourselves as others see us'. In these, non-anthropologists review anthropological books and other works, and discuss the contribution that they make in the light of their own perspectives and fields. The impetus for this feature lies in the challenges that applied anthropologists often face in explaining and promoting the value of anthropological knowledge outside the discipline. We hope that this invitation to reviewers from outside the discipline will prove stimulating and informative to readers about the responses that anthropological insights receive in the wider world, and will suggest how wider communication of our research could be enhanced.

If you would like to contribute to the occasional reviews feature, or if there is something that you would especially like to review (including content other than books), please do get in touch with us to discuss!

\section{Books and documentaries currently available and awaiting review include:}

Armbrust, W. (2019), Martyrs and Tricksters: An Ethnography of the Egyptian Revolution (Princeton, NJ: Princeton University Press).

Bernstein, A. (2019), The Future of Immortality: Remaking Life and Death in Contemporary Russia (Princeton, NJ: Princeton University Press).

Booher, A. and K. Oths (2018), The Last Bonesetter (Watertown, MA: Documentary Educational Resources). Video Resource.

Bowen, J. R. (2016), On British Islam: Religion, Law, and Everyday Practice in Shari'a Councils (Oxford: Princeton University Press).

De La Piedra, M., B. Araujo, and A. Esquinca (2018), Educating across Borders: The Case of a Dual Language Program on the US-Mexico Border (Tucson: University of Arizona Press).

Hull, E. (2017), Contingent Citizens: Professional Aspiration in a South African Hospital (London: Bloomsbury).

Josephides, L. and A. S. Grønseth (eds) (2017), The Ethics of Knowledge Creation: Transactions, Relations and Persons (Oxford: Berghahn).

Kingsolver, A. and S. Balasundaram (eds) (2018), Global Mountain Regions: Conversations towards the Future (Bloomington: Indiana University Press).

Lawrance, B. N. and J. Stevens (eds) (2017), Citizenship in Question: Evidentiary Birthright and Statelessness (Durham, NC: Duke University Press).

Lemelson, R. and A. Pasquino (2017), Tajen (Watertown, MA: Documentary Educational Resources). Video Resource.

Llamojha Mitma, M. and J. P. Heilman (2016), Now Peru Is Mine: The Life and Times of a Campesino Activist (Durham, NC: Duke University Press). MacClancy, J. (ed.) (2017), Anthropology and Public Service: The UK Experience (Oxford: Berghahn).

Maes, K. (2017), The Lives of Community Health Workers: Local Labor and Global Health in Urban Ethiopia (New York: Routledge). 
Mascarenhas, M. (2017), New Humanitarianism and the Crisis of Charity: Good Intentions on the Road to Help (Bloomington: Indiana University Press).

Ong, A. (2016), Fungible Life: Experiment in the Asian City of Life (Durham, NC: Duke University Press).

Povinelli, E. A. (2016), Geontologies: A Requiem to Late Liberalism (Durham, NC: Duke University Press).

Weston, K. (2017), Animate Planet: Making Visceral Sense of Living in a High-Tech Ecologically Damaged World (Durham, NC: Duke University Press).
Yano, C. R. and N. K. A. Akatsuka (eds) (2018), Straight A's: Asian American College Students in their own Words (Durham, NC: Duke University Press).

Zerubavel, E. (2018), Taken for Granted: The Remarkable Power of the Unremarkable (Princeton, NJ: Princeton University Press). 